\title{
SIMULATION OF THE ENERGY PERFORMANCE OF MAIZE PRODUCTION INTEGRATED TO PIG FARMING
}

\section{MÁRCIO L. PERIN ${ }^{1}$, GILBERTO MARTINS ${ }^{2}$, OSMAR DE C. BUENO 3}

\begin{abstract}
The study evaluated the energy performance of pig farming integrated with maize production in mechanized no-tillage system. In this proposed conception of integration, the swine excrement is used as fertilizers in the maize crop. The system was designed involving the activities associated to the pig management and maize production (soil management, cultivation and harvest). A one-year period of analysis was considered, enabling the production of three batches of pigs and two crops of maize. To evaluate the energy performance, three indicators were created: energy efficiency, use of non-renewable resources efficiency and cost of non-renewable energy to produce protein. The energy inputs are composed by the inputs and infrastructure used by the breeding of pigs and maize production, as well as the solar energy incident on the agroecosystem. The energy outputs are represented by the products (finished pigs and maize). The results obtained in the simulation indicates that the integration improves the energy performance of pig farms, with an increase in the energy efficiency $(186 \%)$ as well as in the use of the non-renewable energy resources efficiency $(352 \%)$, while reducing the cost of non-renewable energy to produce protein $(-58 \%)$.
\end{abstract}

KEYWORDS: pig farming, integrated agroecosystems, energy analysis.

\section{SIMULAÇÃO DO DESEMPENHO ENERGÉTICO DA PRODUÇÃO DE MILHO INTEGRADA À SUINOCULTURA}

RESUMO: Foi avaliado o desempenho energético da suinocultura integrada à produção de milho em grão em sistema de plantio direto mecanizado. Nesta concepção de integração proposta, os dejetos suínos são utilizados como fertilizantes na produção de milho. O sistema foi delimitado envolvendo as atividades associadas ao manejo dos suínos e de produção do milho (manejo do solo, cultivo e colheita). O período de análise considerado foi de um ano, o que possibilita a produção de três lotes de suínos e duas safras de milho. Para avaliar o desempenho energético, foram criados três indicadores: eficiência energética, eficiência de uso de fontes não renováveis e o custo de energia não renovável para a produção de proteína. As entradas energéticas são compostas pelos insumos e pela infraestrutura, utilizados na criação dos suínos e na produção de milho, e pela radiação solar incidente no agrossistema. Já as saídas são representadas pelos seus produtos (suínos terminados e o milho). Os resultados obtidos nas simulações apontam que a integração melhora o desempenho energético das granjas suinícolas, aumentando a eficiência energética (186\%) e a eficiência não renovável $(352 \%)$, além de reduzir o custo de energia não renovável para a produção de proteína $(-58 \%)$.

PALAVRAS-CHAVE: suinocultura, agrossistemas integrados, análise energética.

\footnotetext{
${ }^{1}$ Engenheiro e Mestre em Energia, Doutorando, Programa de Pós-Graduação em Energia, Universidade Federal do ABC - UFABC, mlperin@gmail.com.

${ }^{2}$ Prof. Dr., Programa de Pós-Graduação em Energia, Centro de Engenharia, Modelagem e Ciências Sociais Aplicadas, Universidade Federal do ABC - UFABC.

${ }^{3}$ Prof. Dr., Livre Docente em Extensão Rural, Programa de Pós-Graduação em Agronomia - Energia na Agricultura, Departamento de Economia, Sociologia e Tecnologia, Faculdade de Ciências Agronômicas, UNESP - Câmpus de Botucatu.

Recebido pelo Conselho Editorial em: 7-6-2011

Aprovado pelo Conselho Editorial em: 14-6-2012
} 


\section{INTRODUCTION}

As mentioned in CERVI et al. (2010), the expansion of pig farming has resulted in a significant increase in the volume of produced waste, increasing the risks of environmental contamination. The swine excrement show great pollution potential. Thus, this residue must be handled properly, or may cause serious impacts to the ecosystem. In the definition of KUMAREZAN et al. (2009), residue is an energy resource disposed in an inappropriate location; however, this could become an input for other producing processes, if handled correctly. So, the integration of pig farming with other agricultural activities may reduce the risk of environmental contamination, and increase the supply of products in the property.

Several ideas of integration have been proposed, highlighting the association of pig farming and maize production (DAUDÉN \& QUÍLEZ, 2004), fish (TOMAZELLI JR. et al., 2007), sugar cane (LEITE et al., 2009) and pasture (DRUMOND et al., 2006). In addition to these concepts, it has been proposed the use of swine excrement for biogas production (CERVI et al., 2010). Among these concepts above, the integration of pig farming with the grain maize production is predominant (KUNZ et al., 2009). In the integrated pig farming/agriculture system, as this productive concept is called in this study, the waste is collected and stored in dunghills for stabilization, and then distributed in the soil to supply the nutrient requirements for culture.

The energy analysis is an instrument that aids in the evaluation of the efficiency profits obtained with the reuse of pig production residues as productive inputs in the maize cultivation. With the integration of the two agricultural activities, the energy performance tends to increase when compared to non-integrated system. SOUZA et al. (2009) justifies the use of energy analysis in agricultural systems for their applicability in identifying processes with lower efficiency. Additionally, the authors discuss that the evaluation of energy flows in agricultural systems as well as the evaluation of its energy performance, is an important instrument to evaluate the sustainability of the agroecosystems.

Therefore, this study aimed to simulate the energy performance of the production of three batches of 500 pigs integrated to the production of grain maize in no-tillage system in two crops in a year. With these results it was possible to evaluate the influence of the integration of productive activities in the energy performance of the agroecosystems.

\section{MATERIAL AND METHODS}

The object of analysis encompassed the management activities of pigs (called pig farming stage) and the processes that formed the maize production (fertilization of soils with swine excrement, soil preparation, cultivation and maize harvest) called agriculture stage. The integration of activities occurs by the use of excrements produced by pigs as organic fertilizer in maize production. One-year period of analysis was considered, which would allow the production of three batches of pigs and two crops of maize (main crop and off-season). The results obtained by the simulation of the pig farming/agriculture integrated system were compared with the energy performance of an equivalent system, where the activity of pig farming is developed without integration with agriculture.

The energy inputs of the integrated system were associated with the inputs (direct energy), directly expenses in breeding of animals and production of maize, and energy depreciated by the use of infrastructure (indirect energy). The direct energy was evaluated by the product of the physical demands for the agroecosystem by its energetic coefficient. To calculate the indirect energy, we used the method of energy depreciation, which considered using time and equipment useful life (SOUZA et al., 2009; ANGONESE et al., 2006).

In the energetic evaluation of the agroecosystems were assessed commercial energy flows (inputs and infrastructure) and non-commercial energy flows (solar radiation). The energy flows were classified in two forms: renewable and non-renewable. The renewable resources included the 
products originated from the photosynthetic process, such as vegetal products, propagating material, work force, and solar radiation. The non-renewable energy resources included the fossil inputs and/or mineral, such as chemical fertilizers, diesel oil, mineral supplements, pesticides and energy depreciated by use of productive infrastructure. This classification was useful to evaluate the dependence of agroecosystems on non-renewable resources, which availability is finite. A system highly dependent on non-renewable resources tend to have their sustainability compromised (FURLANETO et al., 2009; LAMMERS et al., 2010).

There are several indicators available in the literature, each one constructed in order to facilitate the analysis within the scope proposed by each author (CAMPOS et al., 2003; FURLANETO et al., 2009; SOUZA et al., 2009). The indicators considered in this study were energy efficiency (eq.(1)), non-renewable efficiency (eq.(2)) and the cost of non-renewable protein (eq.(3)):

$$
\begin{aligned}
& \eta=\frac{\sum \text { energy inputs (MJ) }}{\sum \text { energy outputs (MJ) }} \\
& \eta_{\mathrm{NR}}=\frac{\sum \text { energy inputs(M) }}{\sum \text { non-renewable energy inputs(M) }} \\
& \mathrm{C}_{\mathrm{P}_{\mathrm{r}}}=\frac{\sum \text { non }- \text { renewable energy inputs (MJ) }}{\sum \text { produced protein (kg) }}
\end{aligned}
$$

The pig farming stage was shaped having as parameter the technical requirements for the production of a batch of 500 pigs on a unity of growth and termination (UGT). In a year of production can be produced three batches, with average animal ${ }^{-1}$ weight ${ }^{1}$ of $75 \mathrm{~kg}$. The average mortality was estimated at $10 \%$. The production system, that involves management techniques, demand for inputs and infrastructure, was characterized based on the technological pattern of pig farming in southern region of Brazil.

In this study it was considered that the animals were fed with a commercial ration containing $17 \%$ crude protein, whose main components were maize (78\%), soybean meal and wheat (19\%) and vitamin and mineral supplements $(5 \%)$. Regarding the classification of the energy associated with the ration, it was estimated that $33.0 \%$ would be of non-renewable origin and that $67 \%$ would be renewable (PERIN, 2010). The inputs used in pig farming stage are presented in Table 1.

TABLE 1. Quantities and energetic coefficients of inputs used in a year of pig farming (three batches).

\begin{tabular}{lcc}
\hline \multicolumn{1}{c}{ Item } & Quantity & Energetic Coefficient \\
\hline Ration & $414.33 \mathrm{t}$ & $18.00 \mathrm{MJ} \mathrm{kg}^{-1(\mathrm{i})}$ \\
Suckling pigs & $30.00 \mathrm{t}$ & $9.21 \mathrm{MJ} \mathrm{kg}^{-1(i i)}$ \\
Eletric energy & $1.85 \mathrm{MW} \mathrm{h}$ & $3.60 \mathrm{MJ} \mathrm{kWh}^{-1}$ (iii) \\
Work force (man-hour) & $2,257.00 \mathrm{~h}$ & $0.47 \mathrm{MJ} \mathrm{h}^{-1}$ (iv) \\
\hline
\end{tabular}

(i) PERIN (2010); (ii) ANGONESE et al. (2006); (iii) BEN (2009); (iv) SANTOS \& LUCAS JR. (2004).

The average daily production of waste for finishing pigs was estimated at $10.5 \mathrm{~L}_{\text {animal }}{ }^{-1}$ (PERIN, 2010). This estimative took into account, in addition to the feces and urine of the animals, the wasted water in animal drinking places and in the washing of the pigsty. The management in the water level system is the most used technique in UGT farms. This water level is formed by the construction of a small salience on the floor, next to the waste outlet piping (DAGA et al. 2007).

\footnotetext{
${ }^{1}$ The batch of pigs enters in the productive system with an average animal weight of $30 \mathrm{~kg}$ and is delivered with an average animal weight of $130 \mathrm{~kg}$.
} 
The physicochemical characterization of swine excrement was estimated using the data supplied by ASAE (2005) (Table 2). The use of these parameters is based on the hypothesis that, in pig farming industry, with controlled handling and feeding, there is little variance in the composition of the excrements. What differs significantly is the concentration of these elements in the excrements, due to its dilution.

TABLE 2. Characterization of excrements produced by pigs in terms of total solids and NPK Macronutrients.

\begin{tabular}{cc}
\hline Item $^{2}$ & Daily Production by ton of meal \\
\hline Total solid & $11.00 \mathrm{~kg}$ \\
Total nitrogen & $0.52 \mathrm{~kg}$ \\
$\mathrm{P}_{2} \mathrm{O}_{5}$ & $0.41 \mathrm{~kg}$ \\
$\mathrm{~K}_{2} \mathrm{O}$ & $0.35 \mathrm{~kg}$ \\
\hline
\end{tabular}

Source: Adapted from ASAE (2005).

The waste is collected and stored in dunghills for posterior agricultural use. The dunghill is sized considering the daily production of waste, ensuring minimum storage time of 120 days. The energy associated with the use of the dunghill is calculated based on the items that compose its structure (plastic blanket and PVC pipes). The energetic coefficient of the blanket is $130 \mathrm{MJ} \mathrm{kg}^{-1}$ and of the PVC is $120 \mathrm{MJ} \mathrm{kg}^{-1}$ (ANGONESE et al., 2006). Calculating the depreciated energy it was considered the usage time of 1 year, with a lifetime of 20 years (SOUZA et al., 2009). Table 3 shows the other items that make up the pig infrastructure.

TABLE 3. Infrastructure of the pig farming stage: quantities and energetic coefficients.

\begin{tabular}{lccc}
\hline \multicolumn{1}{c}{ Item } & Quantity & Material & Energetic Coefficient \\
\hline Pigsty & $676.20 \mathrm{~m}^{2}$ & Mixed & $956.03 \mathrm{MJ} \mathrm{m}^{-2(1)}$ \\
Silo for ration $(16 \mathrm{t})$ & $9.00 \mathrm{t}$ & Steel & $62.78 \mathrm{MJ} \mathrm{kg}^{-1}$ (i) \\
Transport cart & $20.00 \mathrm{~kg}$ & Steel & $62.78 \mathrm{MJ} \mathrm{kg}^{-1}(\mathrm{i})$ \\
Composter & $20.00 \mathrm{~m}^{2}$ & Masonry & $1,208.17 \mathrm{MJ} \mathrm{m}^{-2}$ (ii) \\
Water tank $(15 \mathrm{~m})$ & $226.00 \mathrm{~kg}$ & Plastic & $130.00 \mathrm{MJ} \mathrm{kg}^{-1(\mathrm{i})}$ \\
\hline
\end{tabular}

(i) ANGONESE et al. (2006); (ii) CAMPOS et al. (2003).

The energy outputs of the pig farming stage are represented by the finishing pigs whose energetic coefficient is $9.21 \mathrm{MJ} \mathrm{kg}^{-1}$ (ANGONESE et al., 2006). The protein production was estimated at $10.4 \mathrm{~kg}$ per each $100 \mathrm{~kg}$ of live pigs (PERIN, 2010).

The excrements produced by the animals are used as organic fertilizers, replacing the use of chemical fertilizer, based on Nitrogen, Phosphorus and Potassium in maize production. The agriculture stage was modeled following the technical script recommended by Embrapa Maize and Sorghum (CRUZ, 2009) for the production of grain maize under mechanized no-tillage. In this script were added the operational requirements for application of the excrements as a biofertilizer.

Table 4 presents the description of the main activities involved, equipment used and fuel demand. It was considered the production of two annual crops. Using the technical script above mentioned, we estimated a productivity of $7 \mathrm{t} \mathrm{ha}^{-1}$ for the first crop (main crop) and $3 \mathrm{tha}^{-1}$ for the second crop (off-season), which totalized an annual production of $10 \mathrm{t} \mathrm{ha}^{-1}$.

\footnotetext{
${ }^{2}$ The production of the $\mathrm{P}_{2} \mathrm{O}_{5}$ and $\mathrm{K}_{2} \mathrm{O}$ compounds is obtained by the mass coefficient of the $\mathrm{P}$ and $\mathrm{K}$ elemental forms by the 2.29 and 1.20 factors, respectively.
} 
TABLE 4. Recommended technical procedures for maize production in one hectare of mechanized no-tillage, fertilized with swine excrement.

\begin{tabular}{lllr}
\hline \multicolumn{1}{c}{ Activity } & \multicolumn{1}{c}{ Equipment } & \multicolumn{1}{c}{ Spent time } & \multicolumn{1}{c}{ Fuel } \\
\hline Herbicide application & Tractor $85 \mathrm{cv}+$ Pulverizer & $0.75 \mathrm{~h} \mathrm{ha}^{-1(\mathrm{i})}$ & $1.00 \mathrm{~L} \mathrm{~h}^{-1}$ \\
Calcareous distribution & Tractor 85 cv + Distributor & $0.13 \mathrm{~h} \mathrm{ha}^{-1(\mathrm{i})}$ & $1.00 \mathrm{~L} \mathrm{~h}^{-1}$ \\
Mechanized tillage & Tractor $85 \mathrm{cv}+$ Planter & $1.60 \mathrm{~h} \mathrm{ha}^{-1(\mathrm{i})}$ & $4.50 \mathrm{~L} \mathrm{~h}^{-1}$ \\
Insecticide application & Tractor $85 \mathrm{cv}+$ Pulverizer & $0.90 \mathrm{~h} \mathrm{ha}^{-1(\mathrm{i})}$ & $1.00 \mathrm{~L} \mathrm{~h}^{-1}$ \\
Mechanized harvest & Harvester $160 \mathrm{cv}$ & $1.45 \mathrm{~h} \mathrm{ha}^{-1(\mathrm{i})}$ & $10.00 \mathrm{~L} \mathrm{~h}^{-1}$ \\
Intern transport & Tractor $85 \mathrm{cv}+$ transport wagon & $1.20 \mathrm{~h} \mathrm{ha}^{-1(\mathrm{i})}$ & $1.00 \mathrm{~L} \mathrm{~h}^{-1}$ \\
Fertilization with excrements & Tractor/distributor Set & $5.21 \mathrm{~h} \mathrm{ha}^{-1(i i i)}$ & $1.00 \mathrm{~L} \mathrm{~h}^{-1}$ \\
\hline
\end{tabular}

(i) Adapted from CRUZ (2009); (ii) Adapted from JOHN DEERE (2010); (iii) PERIN (2010).

The volume of biofertilizers that should be applied in the soil depends on the nutrients extracted by the maize and the concentration of these elements in swine manure. Regarding the extraction of nutrients, this is influenced by the culture productivity, soil characteristics, among other parameters. In the balancing of the fertilization of maize were considered only the NPK (Nitrogen, Phosphorus and Potassium) macronutrients. These elements are the most abundant in swine manure and also those with higher demand for maize. To a productivity of 10t/year we estimated that are extracted on average $238.57 \mathrm{t}$ of Nitrogen, $107.96 \mathrm{t}$ of Phosphorus $\left(\mathrm{P}_{2} \mathrm{O}_{5}\right)$, and $193.71 \mathrm{t}$ of Potassium $\left(\mathrm{K}_{2} \mathrm{O}\right)$ per hectare of cultivation (COELHO \& FRANÇA, 1995).

When the fertilization is performed by organic fertilizer, differences occur between the amounts of nutrients available and the required by the plants. Some nutrients are not readily available, while for others the ability of absorption by the plants is low. SEGANFREDO (1999) recommends defining the nutrient to be supplied entirely by the organic source (nutrient base) and supply the other elements with balanced chemical fertilizer. Among the NPK macronutrients, according to COELHO \& FRANÇA (1995), the phosphorus is the element with lower extraction by the maize. Thus, in this study it was adopted the criterion of phosphorus as a basis element to estimate the volume of waste to be applied and the demanded cultivation area. In this case, there will be deficiencies in the supply of nitrogen and potassium $\left(\mathrm{K}_{2} \mathrm{O}\right)$, which must be supplied by chemical fertilizer. The energetic coefficient of these elements, presented in ANGONESE et al. (2006), is $73 \mathrm{~kg}$ and $9 \mathrm{MJ} \mathrm{kg}^{-1}$, respectively. The demand for fuel was estimated using the Table 4. The energetic coefficient of diesel oil is $35.52 \mathrm{MJ} \mathrm{L}^{-1}$ (BEN, 2009). The other inputs required in this stage are presented in Table 5.

TABLE 5. Inputs used to produce one hectare of maize at two annual crops: quantities and energetic coefficient.

\begin{tabular}{lcc}
\hline \multicolumn{1}{c}{ Item } & Quantity & Energetic Coefficient \\
\hline Herbicide & $8.30 \mathrm{~L} \mathrm{ha}^{-1(\mathrm{i})}$ & $288.00 \mathrm{MJ} \mathrm{kg}^{-1(\mathrm{ii}) 3}$ \\
Insecticides & $1.92 \mathrm{~L} \mathrm{ha}^{-1(\mathrm{i})}$ & $237.00 \mathrm{MJ} \mathrm{kg}^{-1}$ (ii) \\
Maize seeds & $40.00 \mathrm{~kg} \mathrm{ha}^{-1(\mathrm{i})}$ & $33.21 \mathrm{MJ} \mathrm{kg}^{-1}$ (iii) \\
Calcareous & $1.10 \mathrm{t} \mathrm{ha}^{-1}$ (i) & $0.20 \mathrm{MJ} \mathrm{kg}^{-1(\mathrm{iv})}$ \\
Work force (man-hour) & $17.23 \mathrm{~h} \mathrm{ha}^{-1(\mathrm{i})}$ & $0.47 \mathrm{MJ} \mathrm{h}^{-1}(\mathrm{v})$ \\
\hline
\end{tabular}

(i) Adapted from CRUZ (2009); (ii) HÜLSBERGEN et al. (2001); (iii) ALMEIDA et al. (2010); (iv) SALLA et al. (2010); (v) SANTOS \& LUCAS JR. (2004).

In Table 6 are presented the mass and the energetic coefficient of agricultural equipment described in Table 4. To calculate the energy depreciated by the use of this equipment, it was considered a lifetime of 10,000 h, following the procedures adopted by SOUZA et al. (2009).

\footnotetext{
${ }^{3}$ In the conversion of the volume liter unity to $\mathrm{kg}$ of herbicide and insecticide, is adopted the $1 \mathrm{~kg} \mathrm{~L}^{-1}$ density.
} 
The energy output of the agriculture stage is represented by the production of grain maize, whose energetic coefficient is $16.5 \mathrm{MJ} \mathrm{kg}^{-1}$ (SANTOS \& SIMON, 2010). The considered protein concentration in the maize was $79.3 \mathrm{~kg}$ per ton of grains (PERIN, 2010).

TABLE 6. Equipment used for execution of technical scripts of agricultural stage (Table 5) and its corresponding energetic coefficients.

\begin{tabular}{|c|c|c|}
\hline Item & Mass & Energetic Coefficient \\
\hline Tractor $85 \mathrm{cv}$ traction & $4.90 \mathrm{t}^{(\mathrm{i})}$ & $69.83 \mathrm{MJ} \mathrm{kg}^{-1(\mathrm{iv})}$ \\
\hline Harvester $180 \mathrm{cv}$ - platform $4 \mathrm{~m}$ & $9.10 \mathrm{t}^{(\mathrm{i})}$ & $69.83 \mathrm{MJ} \mathrm{kg}^{-1(\mathrm{iv})}$ \\
\hline Pulverizer bar 2,0001 & $7.90 \mathrm{t}^{(\mathrm{i})}$ & $83.71 \mathrm{MJ} \mathrm{kg}^{-1(\mathrm{iv})}$ \\
\hline Planter 7 lines & $2.90 \mathrm{t}^{(\mathrm{i})}$ & $83.71 \mathrm{MJ} \mathrm{kg}^{-1}$ (iv) \\
\hline Transport wagon & $2.00 \mathrm{t}^{\text {(ii) }}$ & $83.71 \mathrm{MJ} \mathrm{kg}^{-1}$ (iv) \\
\hline Distributor of corrective $1.2 \mathrm{~m}^{3}$ & $1.10 \mathrm{t}^{\text {(ii) }}$ & $83.71 \mathrm{MJ} \mathrm{kg}^{-1(\mathrm{iv})}$ \\
\hline Distributor of liquid fertilizer & $1.30 \mathrm{t}^{\text {(iii) }}$ & $57.20 \mathrm{MJ} \mathrm{kg}^{-1(\mathrm{iii})}$ \\
\hline
\end{tabular}

(i) JOHN DEERE (2010); (ii) MARCHESAN (2010); (iii) SOUZA et al. (2009); (iv) CAMPOS et al. (2005).

Regarding the contribution of solar radiation, this was computed by the product of the index of average solar irradiation in the southern region of Brazil and the demand of area in the agroecosystems. According to the Solarimetric Atlas of Brazil (TIBA, 2003), the average annual solar irradiation in the southern region is $15 \mathrm{MJ} \mathrm{m}^{-2}$ (average irradiation between January and December). The demand of area in pig farming stage was estimated at 0.2 ha (PERIN, 2010). In agriculture stage, the demand of area depends on the balance of the maize nutrients.

\section{RESULTS AND DISCUSSION}

The production of live pigs for this period was estimated at $101.25 \mathrm{t}$ (live weight), which represents an animal protein production of $18.25 \mathrm{t}$. The energetic equivalent of this production was estimated at 1.62 TJ. This sum is for the delivery of three batches of 500 pigs per year, average mass of $130 \mathrm{~kg}$, with $10 \%$ of mortality.

The daily production of swine manure was estimated at $5.25 \mathrm{~m}^{3}$. Considering a productive year of 330 days, it was obtained an annual production of $1732.5 \mathrm{~m}^{3}$. To store this volume of waste it would require a dunghill with $630 \mathrm{~m}^{3}$. The materials used in the construction of this dunghill would be $392.5 \mathrm{~kg}$ of plastic blanket $\left(513.7 \mathrm{~m}^{2}\right.$ of blanket with $0.8 \mathrm{~mm}$ thick) and $30 \mathrm{~kg}$ of PVC pipes (AVISERRA, 2010).

The energy inputs of pig farming stage (Table 7) totalized $7.83 \mathrm{TJ}_{\text {year }}{ }^{-1}$, being the ration (renewable and non-renewable fraction) the item with the largest representation in expenditures of the agroecosystem $(95.26 \%)$. Regarding the participation of non-renewable sources in the energetic consumption, this was estimated at $31.4 \%(2.52 \mathrm{TJ})$.

The pig farming is a deficient activity from the energetic point of view, importing much of its energetic demand. The energetic efficiency of pig farming production stage was 0.21 , while the non-renewable efficiency was evaluated at 0.64 . However, the non-renewable cost of the protein production was estimated in $137.96 \mathrm{MJ} \mathrm{kg}^{-1}$. 
TABLE 7. Energy inputs used for pig farming stage in a year of production.

\begin{tabular}{lcr}
\hline \multicolumn{1}{c}{ Item } & Consumed/Depreciated Quantities & Energetic Equivalent \\
\hline Solar radiation & Renewable Inputs & \\
\hline Ration - renewable fraction & $2,000.00 \mathrm{~m}^{2}$ & $30.00 \mathrm{GJ}$ \\
\hline Suckling pigs & $277.60 \mathrm{t}$ & $4,996.82 \mathrm{GJ}$ \\
\hline Electric energy & $30.00 \mathrm{t}$ & $276.30 \mathrm{GJ}$ \\
\hline Work force (man-hour) & $1.85 \mathrm{MWh}$ & $6.65 \mathrm{GJ}$ \\
\hline & $2,257.00 \mathrm{~h}$ & $1.06 \mathrm{GJ}$ \\
\hline Ration - non-renewable fraction & Non-renewable Inputs & $2,461.12 \mathrm{GJ}$ \\
\hline Pigsty & $136.73 \mathrm{t}$ & $29.09 \mathrm{GJ}$ \\
\hline Silo for ration $(16 \mathrm{t})$ & $30.43 \mathrm{~m}^{2}$ & $25.43 \mathrm{GJ}$ \\
\hline Plastic blanket & $405.00 \mathrm{t}$ & $2.30 \mathrm{GJ}$ \\
\hline Water tank (15 m) & $17.66 \mathrm{~kg}$ & $1.32 \mathrm{GJ}$ \\
\hline Composter & $10.17 \mathrm{~kg}$ & $1.09 \mathrm{GJ}$ \\
\hline PVC piping & $0.90 \mathrm{~m}^{2}$ & $0.16 \mathrm{GJ}$ \\
\hline Transport wagon & $1.35 \mathrm{~kg}$ & $0.06 \mathrm{GJ}$ \\
\hline
\end{tabular}

In the agriculture stage, the energy inputs and outputs depend on the area of cultivation. Using the criterion of phosphorus base (concentration of $2.95 \mathrm{~kg} \mathrm{~m}^{-3}$ ), it was estimated that it would take 47.25 ha, for the application of the waste. Table 8 shows the balance of NPK macronutrients for the agriculture stage, based on the total production of these elements by the pigs in the three batches and the amount extracted by the maize in the two annual crops $\left(10 \mathrm{tha}^{-1}\right)$. As the use of agricultural equipment and implements, these are presented in Table 9.

TABLE 8. NPK macronutrients balance of maize in a cultivation area of 47.25 ha in one year of production.

\begin{tabular}{lccc}
\hline \multicolumn{1}{c}{ Nutrient } & $\begin{array}{c}\text { Provided by Swine } \\
\text { Excrement }\end{array}$ & $\begin{array}{c}\text { Nutrients Extracted by the } \\
\text { Maize }\end{array}$ & $\begin{array}{c}\text { Supplied by Chemical } \\
\text { Fertilizer }\end{array}$ \\
\hline Nitrogen & $6,435.00 \mathrm{~kg}$ & $11,272.50 \mathrm{~kg}$ & $4,837.50 \mathrm{~kg}$ \\
\hline Phosphorus $\left(\mathrm{P}_{2} \mathrm{O}_{5}\right)$ & $5,100.98 \mathrm{~kg}$ & $5,100.98 \mathrm{~kg}$ & --- \\
\hline Potassium $\left(\mathrm{K}_{2} \mathrm{O}\right)$ & $4,306.50 \mathrm{~kg}$ & $9,153.00 \mathrm{~kg}$ & $4,846.50 \mathrm{~kg}$ \\
\hline
\end{tabular}

TABLE 9. Energy associated to the depreciation of the equipment that composes the infrastructure of agriculture stage for a year of production in 47.25 ha area of cultivation.

\begin{tabular}{lrrr}
\hline \multicolumn{1}{c}{ Equipment } & Time of Use & Depreciated Mass & Depreciated Energy \\
\hline Tractor $85 \mathrm{cv}$ & $462.25 \mathrm{~h}$ & $203.85 \mathrm{~kg}$ & $14,235.00 \mathrm{MJ}$ \\
\hline Harvester $180 \mathrm{cv}$ & $68.51 \mathrm{~h}$ & $56.11 \mathrm{~kg}$ & $3,918.28 \mathrm{MJ}$ \\
\hline Pulverizer bar 2,000 L & $77.96 \mathrm{~h}$ & $55.43 \mathrm{~kg}$ & $4,640.16 \mathrm{MJ}$ \\
\hline Wagon & $56.70 \mathrm{~h}$ & $10.21 \mathrm{~kg}$ & $854.34 \mathrm{MJ}$ \\
\hline Distributor of corrective $1.2 \mathrm{~m}^{3}$ & $5.91 \mathrm{~h}$ & $0.58 \mathrm{~kg}$ & $48.95 \mathrm{MJ}$ \\
\hline Planter 7 lines & $75.60 \mathrm{~h}$ & $19.73 \mathrm{~kg}$ & $1,651.73 \mathrm{MJ}$ \\
\hline Distributor of liquid fertilizer & $246.08 \mathrm{~h}$ & $28.79 \mathrm{~kg}$ & $1,646.87 \mathrm{MJ}$ \\
\hline
\end{tabular}

Using the criterion of phosphorus base, the use of pig excrement to fertilize the maize planting provided $57 \%$ of the demand for nitrogen, $47 \%$ for potassium and $100 \%$ for phosphorus. Still, in the composition of the energetic matrix of the maize system, the fertilization remained the item with the largest representation in the non-renewable expenditures, with $52.9 \%$. The nitrogen was responsible for $47.7 \%$ of the non-renewable energy inputs. This is due to the characteristics of 
the maize, which requires large amounts of nitrogen and potassium for its cultivation. If the criterion applied was the nitrogen, there would be no spending on fertilizers. However, the phosphorus would be in excess in the system, with the possibility to contaminate the local ecosystem. Table 10 shows the relation of energy inputs of the agriculture stage for a production year.

TABLE 10. Energy inputs used at agriculture stage in one year of production, with 47.25 ha of planting area.

\begin{tabular}{lcr}
\hline & Consumed/Depreciated Quantities & Energetic Equivalent \\
\hline Solar radiation & Renewable Inputs & \\
\hline Work force (man-hour) & $472,500.00 \mathrm{~m}^{2}$ & $7,087,500.00 \mathrm{MJ}$ \\
\hline Seeds & $1,059.96 \mathrm{~h}$ & $62,766.90 \mathrm{MJ}$ \\
\hline & $1,890.00 \mathrm{~kg}$ & $498.18 \mathrm{MJ}$ \\
\hline Herbicide & Non-renewable Inputs & \\
\hline Insecticide & $784.35 \mathrm{~kg}$ & $225,892.80 \mathrm{MJ}$ \\
\hline Nitrogen & $181.44 \mathrm{~kg}$ & $43,001.28 \mathrm{MJ}$ \\
\hline Potassium & $4,837.50 \mathrm{~kg}$ & $353,137.50 \mathrm{MJ}$ \\
\hline Fuel & $4,306.50 \mathrm{~kg}$ & $38,758.50 \mathrm{MJ}$ \\
\hline Calcareous & $1,415.00 \mathrm{~L}$ & $50,260.77 \mathrm{MJ}$ \\
\hline Equipments depreciation & $51.98 \mathrm{t}$ & $8.84 \mathrm{MJ}$ \\
\hline
\end{tabular}

The energy inputs of the agriculture stage totalized 7.9TJ, while the outputs were estimated at $7.8 \mathrm{TJ}$ (on production of $472.5 \mathrm{t}$ of grain maize). Thus, the energetic efficiency of agriculture stage was 0.99 . The efficiency of use of non-renewable energy was estimated at 10.53 .

Regarding the protein production, this was estimated to be $37.33 \mathrm{t}_{\text {year }}{ }^{-1}$. Having as base a demand for non-renewable inputs of $740.66 \mathrm{GJ}$, it is obtained a non-renewable energetic cost of $13.33 \mathrm{MJ} \mathrm{kg}^{-1}$ to produce maize protein in integrated systems.

Table 11 shows the energetic matrix consolidated to the integrated system for a one-year production. In the integrated system, the energetic efficiency of the integrated system was evaluated in 0.6. The non-renewable efficiency was estimated at 2.89. The non-renewable cost of protein production was estimated to be $58.63 \mathrm{MJ} \mathrm{kg}^{-1}$. Comparing the obtained results of the integrated system with the evaluated data for non-integrated pig farming, it is clear that the integration has greatly improved the energy performance of pig farms. With the integration, the energetic efficiency increased $186 \%$ non-renewable efficiency $352 \%$. The cost of non-renewable energy for protein production was reduced $58 \%$.

The results obtained in the simulations show the strong participation of two components: the pig ration $(47.4 \%)$ and solar radiation $(45.3 \%)$. The strong participation of the ration is because of the characteristics of the pig culture. The animals are confined. Thus, all the metabolic energy that the animal needs must be provided by rations. This fact justifies the strong participation of the ration in the energetic total expenditures integrated system. In non-confined creations, part of this energy could be supplied by non-commercial energetic sources. However, the contribution of solar radiation in the total expenditure of energy is due to a high demand for area by the system (47.45 ha). Although solar radiation is not a commercial input, its computation in total expenditure highlights the importance of the energetic matrix of the integrated system. 
TABLE 11. Energetic matrix from integration between pig farming and maize cultivation for one year production.

\begin{tabular}{lcc}
\hline \multicolumn{1}{c}{ Item } & Energy & Participation \\
\hline Pig Farming Stage & Energetics Inputs & \\
\hline Renewable & $7,828.94$ GJ & $49.8 \%$ \\
\hline Non-renewable & $5,310.83$ GJ & $67.8 \%$ \\
\hline Agriculture Stage & $2,518.10$ GJ & $32.2 \%$ \\
\hline Renewable & $7,891.43$ GJ & $50.2 \%$ \\
\hline Non-renewable & $7,150.77$ GJ & $90.6 \%$ \\
\hline Integrated System & 740.66 GJ & $9.4 \%$ \\
\hline Renewable & $15,720.36$ GJ & $100.0 \%$ \\
\hline Non-renewable & $12,461.60$ GJ & $79.3 \%$ \\
\hline Pig Farming Stage & $3,258.77$ GJ & $20.7 \%$ \\
\hline Agriculture Stage & Energetics Outputs & $17.2 \%$ \\
\hline Integrated System & $7,796.25$ GJ & $82.8 \%$ \\
\hline
\end{tabular}

The annual maize production was estimated at $472.5 \mathrm{t}$. In the composition of the ration of pigs, this product represents $79 \%$ of the inputs used. Considering an annual consumption of ration in the order of $414 \mathrm{t}$, it was estimated that the demand for maize would be of $327 \mathrm{t}^{\text {year }}{ }^{-1}$. Thus, under normal conditions of crop, the integrated system would be self-sufficient in maize, getting to produce a surplus of $145 \mathrm{t}_{\text {year }}{ }^{-1}$. This surplus could be sold or used in other production processes of the property.

The consumption of protein in pig farming production was $58.00 \mathrm{t} \mathrm{year}^{-1}$. The production was $55.72 \mathrm{t}$ year $^{-1}$, being $34 \%$ of animal protein and $66 \%$ of vegetable origin. Thus, it was estimated that the integrated system would recycle $96 \%$ of the protein invested in the productive stage in the form of ration. However, we must consider that these results consider a full season without breaks of productivity. Any eventual environmental bad weather and/or deficient management of the system could compromise the results.

Furthermore, the ability of the cultures to recycle applied nutrients is fundamental to properly estimate the volume of waste to be applied. When the agricultural use is the only destination of these wastes, the availability of agricultural area becomes a limiting criterion of the number of animals that can be created on the property. Thus, a plan for the batch of pigs must be done to be appropriate to the agrarian reality of the pig farms.

The total area demanded by this integrated pig farming/agriculture system proposed was 47.45 ha. The pig producers who do not have this agricultural area on their properties should reduce the size of the batch of pigs or hire the remaining area with third parties. However, should be assessed the feasibility of exporting waste. The high dilution, common in most properties, makes this practice not viable.

The effectiveness of the integration in the energetic performance of the agroecosystems depends on the fulfillment of production criteria recommended in the technical scripts presented. Otherwise, may reduce the energetic performance, and make impracticable the application of this conception of production. In addition, there are restrictions on the implantation of integrated systems related to the fulfillment of the criteria of technical feasibility (availability of technology, water and farming areas) economic (market for generated products), licensing activities and management and operation of the systems. 


\section{CONCLUSIONS}

The simulation of the energetic performance of the integrated system of maize production with pig farming proved to be efficient, increasing the energetic performance and reducing the environmental impacts of the agroecosystems. The swine manure could supply $57 \%$ of the demand for nitrogen, $47 \%$ for potassium and $100 \%$ of the phosphorus needs. Comparing the pig farming stage not integrated with the integrated system, it was found that the energetic efficiency increased by $186 \%$ and the non-renewable efficiency by $352 \%$. Moreover the cost of non-renewable energy for protein production was reduced by $58 \%$. Furthermore, with the integration, $96 \%$ of the protein invested in the agroecosystem in the form of ration could be recovered in the form of vegetable (grain maize) and animal (meat). It is noteworthy, however, the need to accordingly plan the size of the pig batch to be suitable for the availability of the agricultural area in the property.

\section{ACKNOLEGMENTS}

Federal University of $\mathrm{ABC}$ for the financial support to this research.

\section{REFERENCES}

ALMEIDA, L. C. F.; BUENO, O. C.; ESPERANCINI, M. S. T.. Avaliação energética e econômica da cultura do milho em assentamento rural, Iperó-SP. Revista Energia na Agricultura, Botucatu, v.25, n.2, p.105-122, 2010.

ANGONESE, A. R.; CAMPOS, A. T.; ZACARKIM, C. E.; MATSUO, M. S.; CUNHA, F. Eficiência energética de sistema de produção de suínos com tratamento de resíduos em biodigestor. Revista Brasileira de Engenharia Agrícola e Ambiental, Campina Grande, v.10, n.3, p.745-750, 2006.

ASAE - AMERICAN SOCIETY OF AGRICULTURAL ENGINEERS. Manure production and characteristics. Standard ASAE D384.2. ASAE, 2005.

AVISERRA. Esterqueiras: descrição do produto e requisito de obras civis. Caxias: AVISERRA, 2010. Catálogo.

BEN - BALANÇO ENERGÉTICO NACIONAL 2009: ano base 2008. Rio de Janeiro: EPE, 2009.

CAMPOS, A. T.; SAGLIETTI, J. R. C.; BUENO, O. C.; CAMPOS, ALOÍSIO T.; KLOSOWSKI, E. S.; GASPARINO, E. Custo energético de construção de uma instalação para armazenamento de feno. Ciência Rural. Santa Maria, v.33, n.4, p.667-672, 2003.

CAMPOS, A. T.; SAGLIETTI, J. R. C.; CAMPOS, A. T.; BUENO, O. C. Análise energética na produção de feno de cynodon dactylon (L.) pers. Engenharia Agrícola, Jaboticabal, v.25, n.2, p.349-358, maio/ago. 2005.

CERVI, R. G.; ESPERANCINI, M. S. T.; BUENO, O. C. Viabilidade econômica da utilização do biogás produzido em granja suinícola para geração de energia elétrica. Engenharia Agrícola, Jaboticabal, v.30, n.5, p.831-844, set./out. 2010.

COELHO, A. M.; FRANÇA, G. E. Seja o doutor do seu milho. 2.ed. Piracicaba: POTAFOS, 1995. (Arquivo do Agrônomo, 2.).

CRUZ, J. C. (Ed.). Cultivo do milho. Sistemas de produção 2. 5.ed. Sete Lagoas: Embrapa Milho e Sorgo, 2009.

DAGA, J.; CAMPOS, A. T.; FEIDEN, A.; KLOSOWSKI, E. S.; CÂMARA, R. J. Análise da adequação ambiental e manejo dos dejetos de instalações para suinocultura em propriedades na Região Oeste do Paraná. Engenharia Agrícola, Jaboticabal, v.27, n.3, p.587-595, 2007.

DAUDÉN, A.; QUÍLEZ, D. Pig slurry versus mineral fertilization on corn yield and nitrate leaching in a Mediterranean irrigated environment. European Journal of Agronomy, Montrouge, n.21, p.7-

19, 2004. 
DRUMOND, L. C. D.; ZANINI, J. R.; AGUIAR, A. P. A.; RODRIGUES, G. P.; FERNANDES, A. L. T. Produção de matéria seca em pastagem de tifton 85 irrigada, com diferentes doses de dejeto líquido de suíno. Engenharia Agrícola, Jaboticabal, v.26, n.2, p.426-433, set./dez. 2006.

FURLANETO, F. P. B.; ESPERANCINI, M. S. T.; BUENO, O. C. Análise energética do bicultivo de peixes na Região do Médio Paranapanema, Estado de São Paulo. Revista Energia na Agricultura, Botucatu, v.24, n.2, p.92-105, 2009.

HÜLSBERGEN, K.; FEILB, B.; BIERMANNA, S.; RATHKEA, G. -W.; KALKC, W. -D.; DIEPENBROCK, W. A method of energy balancing in crop production and its application in a long-term fertilizer trial. Agriculture, Ecosystems and Environment, Amsterdam, v.86, p.303-321, 2001.

JOHN DEERE. Especificações técnicas de produtos. John Deere Brasil, 2010. Catálogo. KUMARESAN, A.; PATHAK, K. A.; BUJARBARUAH, K.; VINOD, M. K. Analysis of integrated animal-fish production system under subtropical hill agro ecosystem in India: Growth performance of animals, total biomass production and monetary benefit. Tropical Animal Health and Production, Edimburg, v.41, n.3, p.385-391, 2009.

KUNZ, A.; MIELE, M.; STEINMETZ, R.L.R. Advanced swine excrement treatment and utilization in Brazil. Bioresource Technology, Essex, n.100, p.5485-5489, 2009.

LAMMERS, P. J.; HONEYMAN, M. S.; HARMON, J. D.; HELMERS, M. J. Energy and carbon inventory of Iowa swine production facilities. Agricultural Systems, Essex, v.103, n.8, p.551-561, 2010.

LEITE, G. F.; CUNHA NETO, F. R.; RESENDE, A. V. Produtividade agrícola da cana-de-açúcar adubada com dejetos líquidos de suínos. Ciência e Agrotecnologia, Lavras, v.33, n.1, p.132-138, 2009.

MARCHESAN. Especificações técnicas de produtos. Matão: Marchesan Implementos e Máquinas Agrícolas “TATU”, 2010. Catálogo.

PERIN, M. L. Simulação do desempenho energético e da demanda de área em agrossistemas integrados à suinocultura. 2010. 165 f. Dissertação (Mestrado em Energia) - Universidade Federal do ABC, Santo André, 2010.

SALLA, D. A.; FURLANETO, F. P. B.; CABELLO, C.; KANTHACK, R. A. D. Estudo energético da produção de biocombustível a partir do milho. Ciência Rural, Santa Maria, v.40, n.9, p.20172022, 2010.

SANTOS, R. R.; SIMON, E. J. Análise energética do milho em sistema de plantio direto, no Assentamento Rural da Fazenda Pirituba, Itaberá-SP. Energia na Agricultura, Botucatu, v.25, n.1, p.121-137, 2010.

SANTOS, T. M. B.; LUCAS JR., J. Balanço energético em galpão de frangos de corte. Engenharia Agrícola, Jaboticabal, v.24, n.1, p.25-36, jan./abr. 2004.

SEGANFREDO, M. A. Os dejetos suínos são um fertilizante ou um poluente do solo? Cadernos de Ciência e Tecnologi,. Brasília, v. 16, p. 129-141, 1999.

SOUZA, C. V.; CAMPOS, A. T.; BUENO, O. C.; SILVA, E B. Análise energética em sistema de produção de suínos com aproveitamento dos dejetos como biofertilizante em pastagem. Engenharia Agrícola, Jaboticabal, v.29, n.4, p.547-557, out./dez. 2009.

TIBA, C. (Ed.). Atlas Solarimétrico do Brasil. Recife: Ed. Universitária da UFPE, 2003. CD-ROM.

TOMAZELLI JR., O.; CASACA, J. M.; DITTRICH, R. Qualidade de água em policultivos de peixe integrados à suinocultura. Revista Agropecuária Catarinense, Florianópolis, v.20, n.2, p.72$75,2007$. 